\title{
PERAN COMPETITIVE ADVANTAGE DALAM PENGEMBANGAN AGROWISATA ABIAN SALAK DI KABUPATEN KARANGASEM
}

\author{
Ni Luh Ketut Ayu Sudha Sucandrawati 1, \\ Ni Ketut Murdani ${ }^{2}$ \\ Program Studi Manajemen, Fakultas Ekonomi \\ Universitas Mahendradatta \\ Jl. Ken Arok No.12, Peguyangan Denpasar Utara, Bali 80115 \\ ayusucandra89@gmail.com

\begin{abstract}
Abstrak - Tujuan dari penelitian ini adalah untuk meningkatkan keunggulan bersaing dari Agrowisata Abian Salak di Kabupaten Karangasem. Bali terkenal dengan pariwisata budayanya. Bali juga mengembangkan Agrowisata sebagai wisata alternatif . Untuk menjadi unggul dan bersaing, dalam pengembangan industri pariwisata ini tidak terlepas dari kreatifitas dan inovasi dari pengelolanya. Agrowisata Abian Salak telah melakukan inovasi dalam menciptakan produk kopi dari biji Salak diberi merk Salacca Coffee Bean. Penelitian dilaksanakan dengan metode kualitatif deskriptif . Keunggulan bersaing dari Agrowisata Abian Salak berupa keunikan buah salak dan produk kopi dari biji Salak yang berkualitas.
\end{abstract}

\section{Kata Kunci : agrowisata, keunggulan bersaing, produk}

\begin{abstract}
The purpose of this study is to increase the competitive advantage of Abian Salak Agro Tourism in Karangasem Regency . Bali is famous for its cultural tourism . Bali is also developing Agro-tourism as an alternative tourism . To be superior and compete, in the development of this tourism industry can not be separated from the creativity and innovation of the managers . Abian Salak Agro Tourism has made innovations in creating coffee products from Salak beans given the brand Salacca Coffee Bean . Research carried out by the method of qualitative descriptive. The competitive advantage of Abian Salak Agro Tourism is its unique fruit bark and product coffee from beans Salak are qualified.
\end{abstract}

Keywords : agro tourism, competitive advantage, Product 


\section{PENDAHULUAN}

Bali sangat dikagumi di seluruh Dunia karena pariwisata budayanya. Bali telah beberapa kali terpilih menjadi destinasi terbaik versi majalah terkenal dari Singapore Magazine sejak tahun 2010 . Pariwisata Bali berkembang pesat dengan keunikannya bahkan Bali dijuluki sebagai the Island of God. Kekaguman dunia terhadap budaya Bali karena semua kegiatan wisata dan budaya masyarakatnya bernafaskan agama Hindu. Pertumbuhan kunjungan Wisatawan mancanegara ke Indonesia, menurut Badan Statistik Nasional bertumbuh mencapai 14 persen. Dari segi kunjungan wisatawan ke Indonesia menurut sumber Asean Secretary (2018) Indonesia menduduki peringkat ke empat setelah Thailand, Malaysia, dan Singapore.

Dalam Undang-Undang Nomor 10 tahun 2009 tentang kepariwisataan disebutkan bahwa penyelenggaraan kepariwisataan ditujukan untuk meningkatkan pendapatan nasional dalam rangka meningkatkan kesejahteraan dan kemakmuran rakyat, memperluas dan memeratakan kesempatan berusaha dan lapangan kerja, mendorong pembangunan daerah, memperkenalkan dan mendayagunakan obyek dan daya tarik wisata di Indonesia serta memupuk rasa cinta tanah air dan mempererat persahabatan antar bangsa. Dalam Peraturan Daerah Provinsi Bali, Nomor 2 tahun 2012 tentang Kepariwisataan Budaya
Bali disebutkan kepariwisataan adalah keseluruhan kegiatan yang terkait dengan pariwisata dan bersifat multidimensi serta multidisiplin yang muncul sebagai wujud kebutuhan setiap orang dan negara serta interaksi antara wisatawan dan masyarakat setempat, sesama wisatawan, pemerintah pusat, pemerintah daerah dan pengusaha.

Bali menjadi destinasi wisata terkenal di Dunia Internasional, karena keunikan yang dimilikinya seperti pariwisata budaya, wisata alam, dan pantai yang indah. Dengan menjadi tuan rumah penyelenggara Pertemuan Tahunan International Monetery Fund (IMF)-World Bank 2018 dapat memberi dampak positif bagi sektor pariwisata di Pulau Bali .

Badan Pusat Statistik Provinsi Bali, mencatat kedatangan wisawatan mancanegara yang datang ke Pulau Bali periode Januari-Desember 2018 mencapai 6.070.473 orang, kunjungan naik dibanding tahun 2017. Jumlah tersebut mencapai 72 persen dari total kunjungan wisatawan mancanegara tahun 2017. Berdasarkan asal negara, wisman dari Tiongkok yang paling banyak berkunjung ke Bali, yaitu mencapai 962 ribu kemudian diikuti dari Australia 763 ribu kunjungan. Kunjungan wisman ke Bali mencapai puncaknya pada tahun 2017 dan pertumbuhan tertinggi dicapai pada tahun 2004 . 
Perkembangan Desa Wisata di Bali cukup menjanjikan dan jumlahnya semakin meningkat, terbukti sejak tahun 2017 sampai saat ini ada 100 desa wisata yang telah ditetapkan melalui Surat Keputusan Bupati dan Wali Kota di masing-masing Kabupaten di Bali. Dibawah ini terlihat data Desa Wisata dan kawasan pariwisata di Bali. Agrowisata di Bali telah berkembang pesat dengan berbagai keunikannya. Hasil pertanian dan hasil kebun dapat diberdayakan untuk dijadikan daya tarik wisata.

Tabel 1

Data Desa Wisata dan Kawasan Pariwisata

\begin{tabular}{|c|l|c|c|}
\hline NO & Kabupaten/Kota & $\begin{array}{c}\text { Jumlah } \\
\text { Kawasan } \\
\text { Pariwisata }\end{array}$ & Desa Wisata \\
\hline 1 & Denpasar & 1 & 6 \\
\hline 2 & Badung & 3 & 11 \\
\hline 3 & Gianyar & 2 & 9 \\
\hline 4 & Tabanan & 1 & 23 \\
\hline 5 & Klungkung & 1 & 18 \\
\hline 6 & Bangli & - & 31 \\
\hline 7 & Karangasem & 3 & 25 \\
\hline 8 & Buleleng & 3 & 31 \\
\hline 9 & Jembrana & 2 & 6 \\
\hline & Total & 16 & 100 \\
& & & \\
\hline
\end{tabular}

Sumber : Dinas Pariwisata Provinsi Bali 2019

Dari tabel diatas dapat dilihat berkembangnya desa wisata yang ada di Bali. Namun dalam pertumbuhannya desa wisata belum mampu mencapai target yang diinginkan. Banyak dari pengelola desa wisata ini belum memahami bagaimana cara pengelolaan dan menejemen pelayanan dari Desa wisata ini agar tetap berkembang. Beberapa kreteria dari desa wisata belum secara optimal dilaksanakan. Desa wisata sebagai wisata alternatif sangat bermanfaat bagi ekonomi masyarakat pedesaan. Kendala yang banyak dialami dari pengelola desa wisata adalah masalah infrastruktur yang belum memadai seperti akses jalan menuju lokasi desa wisata terlalu sempit sulit dilalui kendaraan umum. Informasi yang kurang jelas tentang lokasi desa wisata. SDM dan pelayanan yang belum maksimal terhadap wisatawan khususnya dalam 
pelayanan di ke obyek wisata, sehingga sering terjadi complain. Misalnya pelayanan yang lamban di Restoran kurang puas terhadap makanan yang dipesan tidak sesuai keinginan para wisatawan. Informasi yang kurang jelas tentang keberadaan desa wisata. Wisatawan datang ke tempat wisata karena ingin mendapatkan kepuasan sehingga timbul keinginan untuk datang lagi sebagai tamu ( repeater guests ). Desa wisata di Bali banyak memiliki daya tarik wisata seperti agrowisata, wisata alam, wisata buatan dan wisata air. Tidak cukup unik saja tetapi bagaimana agar desa wisata atau agrowisata yang memiliki keunggulan kompetitif (competitive advantages) . Kreteria desa wisata di beberapa Kabupaten di Bali belum memadai sehingga keberlajutan desa wisata menjadi kendala. Dalam penelitian wisata alternatif penulis khusus meneliti tentang desa wisata yang memiliki keunikan seperti Agrowisata Abian Salak di desa Sibetan, Karangasem. Desa Sibetan banyak memiliki keunikan yang dapat dilihat wisatawan yaitu keindahan alam pegunungan yaitu Gunung Agung. .Hamparan sawah yang berterasering dan perkebunan salak yang luas terkenal dengan buah salak yang manis dan salak gula pasir. Desa wisata di Bali memiliki keunikan dan keindahan tersendiri. Penulis tertarik meneliti Agrowisata di Desa Sibetan ini karena desa ini memiliki produk buah salak yang dapat dibuat berbagai inovasi . Buah salak jika diolah menjadi makanan camilan akan bisa dibuat kripik salak yang gurih. Salak juga dapat diolah menjadi minuman yang berkualitas. Biji salakpun dapat diolah menjadi sebuah produk kopi khusus menjadi kopi bubuk yang enak. Kebun salak yang terbentang luas dikelola para petani dengan merapikan kebun salak dengan tanaman tumpangsari. Keikutsertaan masyarakat sebagai petani salak, sangat membantu dalam menjaga keasrian lingkungan. Kreatifitas dari masyarakat dalam mengembangkan Agrowisata Abian Salak ini merupakan keunggulan bersaing dari desa wisata ini.

Keunggulan bersaing ( competitive advantage ) dari Agrowisata Abian ini adalah kemampuan untuk bersaing dengan desa wisata dari kabupaten lain di Bali. Produk unik kopi dari biji salak ini diberi nama Salacca Coffee Bean. Rasa kopi ini cukup bersaing dengan kopi lainnya di pasaran. Menurut Porter ( 1991 ), suatu negara memperoleh keunggulan kompetitif ( competitive advantage) jika perusahaan yang ada di negara tersebut kompetitif. Daya saing suatu negara ditentukan oleh kemampuan industri melakukan inovasi dan meningkatkan kemampuannya. Perusahaan memperoleh keunggulan bersaing (Competitive Advantage) karena tekanan dan tantangan. Perusahaan menerima manfaat dari adanya persaingan di pasar domestik, supplier domestik yang agresif, serta pasar lokal yang memiliki 
permintaan tinggi. Perbedaaan dalam nilai-nilai nasional, budaya, struktur ekonomi, institusi, dan sejarah semuanya memberi kontribusi pada keberhasilan dalam persaingan. Perusahaan menjadi kompetitif melalui inovasi yang dapat meliputi peningkatan teknis proses produksi atau kualitas produk. Ming Su, et al. (2019) menyatakan adanya hubungan yang saling mendukung antara agrowisata dalam kegiatan pertanian dan ekonomi tradisional sehingga wisata desa memiliki keunggulan komparatif yang menciptakan daya saing (competitiveness). Budaya yang berkelanjutan dan seringnya ada interaksi diantara anggota masyarakat suatu komunitas akan meningkatkan keunggulan bersaing dari wisata desa karena unsur budaya masyarakat dapat dijadikan investasi pariwisata (Nicely dan Sydnor, 2015).

\section{KAJIAN TEORI}

\section{Agrowisata}

Agrowisata merupakan terjemahan dari istilah bahasa inggris, Agrotourism. Agro berarti pertanian dan tourism berarti pariwisata/ kepariwisataan. Agrowisata adalah berwisata ke daerah pertanian. Pertanian dalam arti luas mencakup pertanian rakyat, perkebunan, peternakan, dan perikanan (Sudiasa, 2005). Dikatakan oleh Yoeti (2000) bahwa agrowisata merupakan salah satu alternatif potensial untuk dikembangkan di desa. Kemudian batasan mengenai Agrowisata dinyatakan bahwa Agrowisata adalah suatu jenis pariwisata yang khusus menjadikan hasil pertanian, peternakan, perkebunan sebagai daya tarik bagi wisatawan.

Di samping itu yang termasuk dalam agrowisata adalah perhutanan dan sumber daya pertanian. Perpaduan antara keindahan alam, kehidupan masyarakat pedesaan dan potensi pertanian apabila dikelola dengan baik dapat mengembangkan daya tarik wisata. Dengan berkembangnya agrowisata di satu daerah tujuan wisata akan memberikan manfaat untuk peningkatan pendapatan masyarakat dan pemerintahan, dengan kata lain bahwa fungsi pariwisata dapat dilakukan dengan fungsi budi daya pertanian dan pemukiman pedesaan dan sekaligus fungsi konservasi (Gumelar, 2010).

Agrowisata dianggap sebagai " bentuk pariwisata " dan itu adalah paralel pengembangan kegiatan yang bertujuan meningkatkan perekonomian daerah perdesaan, dengan dukungan produksi pertanian lokal, produksi pertanian lokal ringan, pemasaran, pasokan layanan wisata skala kecil dan promosi kekayaan budaya dan alamiah masingmasing daerah ( Fraidaki dan Karagiannis , 2012 ).

Agrowisata telah ditetapkan sebagai istilah ilmu ekonomi dan memang demikian sering digunakan oleh mereka yang bekerja dengan masalah ekonomi pedesaan atau pariwisata ekonomi. 


\section{Pariwisata}

Menurut

Pariwisata Dunia (UNWTO), pariwisata termasuk kegiatan orang-orang yang bepergian dan tinggal di tujuan dan daerah selain itu yang merupakan lingkungan biasa mereka (misalnya tempat tinggal permanen mereka) dan untuk periode waktu yang tidak melebihi satu tahun, untuk tujuan rekreasi, kepuasan akan kebutuhan profesional mereka. Definisi ini membantu mengidentifikasi kegiatan wisatawan baik domestik maupun mancanegara. Kata "pariwisata" mengacu pada semua kegiatan wisatawan yang menginap atau berkunjung ( Delitheou dan Georgakopoulou, 2017 ).

Fennel

(2003), mendefenisikan pariwisata sebagai sistem yang saling terkait yang mencakup wisatawan dan jasa terkait yang disediakan serta dimanfaatkan (fasilitas, atraksi, transportasi, dan akomodasi) untuk menyokong kegiatan mereka. Menurut Undang-undang No. 10 Tahun 2009 tentang Kepariwisataan adalah kegiatan yang dilakukan oleh seseorang atau sekelompok orang dengan mengunjungi tempat tertentu untuk tujuan rekreasi, pengembangan pribadi, atau mempelajari keunikan daya tarik wisata yang dikunjungi dalam jangka waktu sementara. Pariwisata dibagi menjadi dua kategori utama yaitu pariwisata massal dan pariwisata alternatif. Pariwisata massal mengacu pada aktivitas banyak orang yang berbeda, sementara pariwisata alternatif adalah bentuk pariwisata yang kompatibel dengan lingkungan dan sosial, nilai-nilai wilayah yang memungkinkan masyarakat tuan rumah dan pengunjung untuk menikmati interaksi positif yang berharga ntuk berbagi pengalaman di semua tingkatan, Delitheou et al. ( 2016

Pariwisata Budaya ( Cultural Tourism )

Pariwisata budaya sebagai salah satu produk pariwisata merupakan jenis pariwisata yang disebabkan adanya daya tarik dari seni budaya suatu daerah. Pariwisata budaya pada intinya merupakan jenis pariwisata yang menawarkan kebudayaan yang berupa atraksi budaya baik yang bersifat tangibel atau konkret maupun intangibel atau abstrak, juga yang bersifat living culture (budaya yang masih berlanjut) dan cultural heritage (warisan budaya masa lalu), sebagai daya tarik utama untuk menarik kunjungan wisatawan. Dalam living culture, unsur-unsur yang bisa dijadikan sebagai daya tarik antara lain tradisi suatu suku bangsa tertentu, upacara dan ritual keagamaan, seni pertunjukan. Sedangkan dalam cultural heritage, daya tarik yang ditawarkan dapat berupa bendabenda peninggalan sejarah dan purbakala, lansekap budaya. Dalam era global sekarang ini muncul kecenderungan bahwa masyarakat ingin memahami kebudayaan diluar lingkungannya.

Desa Wisata ( Rural Tourism ) 
Ada beberapa definisi mengenai desa wisata yaitu antara lain, desa wisata adalah suatu bentuk intergrasi antara atraksi, akomodasi, dan fasilitas pendukung yang disajikan dalam suatu struktur kehidupan masyarakat yang menyatu dengan tatacara dan tradisi yang berlaku, Nuryanti ( 1993). Menurut Inskeep (1991), memberikan definisi desa wisata sebagai wisata pedesaan dimana sekelompok kecil wisatawan tinggal di alamat dan dekat dengan suasana tradisional, sering di desa-desa yang terpencil dan belajart entang kehidupan pedesaan dan lingkungans setempat, Pariwisata menurut Hadiwijoyo (2012) mendefinisikan desa wisata sebagai suatu kawasan pedesaan yang mencerminkan keaslian pedesaan baik dari kehidupan sosial ekonomi, sosial budaya, adat istiadat, kehidupan sehari-hari, memiliki arsitektur bangunan dan struktur tata ruang desa yang khas, atau kegiatan perekonomian yang unik dan menarik serta mempunyai potensi untuk dikembangkannya berbagai komponen kepariwisataan, misalnya : atraksi, akomodasi, makanan minuman, dan kebutuhan wisata lainnya.

\section{Keunggulan} (Competitive Advantage )

Keunggulan Bersaing Competitive Advantage ), diperkenalkan pertama kali sebagai konsep pada tahun 1985 oleh Porter dalam tulisannya berjudul "Competitive Advantage: Creating and Sustaining Superior Performance". Porter ( 1980 ) sebelumnya menggunakan istilah strategi kompetitif dalam tulisannya berjudul "Competitive Strategy: Techniques for Analyzing Industries and Competitors". Porter (1980) dalam tulisan sebelumnya mengusulkan strategi-strategi generik untuk keunggulan kompetitif. Kemudian pada tahun 1985, Porter memberikan gambarannya tentang keunggulan bersaing, sebagai jantung dari kinerja perusahaan dalam pasar yang bersaing. Keunggulan bersaing

Competitive Advantage ) adalah tentang bagaimana sebuah perusahaan benar-benar menempatkan strategi-strategi generik ke dalam praktik, Porter ( 1985 ). Lebih lanjut menurut Porter (1985), keunggulan kompetitif bertumbuh secara fundamental dari nilai yang memungkinkan perusahaan untuk menciptakan nilai itu bagi para pembelinya melebihi biaya yang dikeluarkan perusahaan untuk menciptakannya

Pada dasarnya setiap perusahaan yang bersaing dalam suatu lingkungan industri mempunyai keinginan untuk dapat lebih unggul dibandingkan pesaingnya. Umumnya perusahaan menerapkan strategi bersaing ini secara eksplisit melalui kegiatankegiatan dari berbagai departemen fungsional perusahaan yang ada. Pemikiran dasar dari penciptaan strategi bersaing berawal dari pengembangan formula umum mengenai bagaimana bisnis akan dikembangkan, apakah sebenarnya yang menjadi tujuannya dan 
kebijakan apa yang akan diperlukan untuk mencapai tujuan tersebut. Pengertian keunggulan bersaing (competitive advantage) sendiri memiliki dua arti yang berbeda tetapi saling berhubungan. Pengertian pertama menekankan pada keunggulan atau superior dalam hal sumber daya dan keahlian yang dimiliki perusahaan.

Perusahaan yang memiliki kompetensi dalam bidang pemasaran, manufacturing, dan inovasi dapat menjadikannya sebagai sumber-sumber untuk mencapai keunggulan bersaing. Melalui ketiga bidang kompetensi tersebut, perusahaan dapat mengembangkan strategi sehingga dapat menghasilkan produk yang laku di pasaran.

\section{METODE}

Penelitian ini menggunakan penelitian kualitatif dengan mendeskripsikan peran keunggulan bersaing ( Competitive Advantage ) dalam pengembangan Agrowisata Abian Salak di Kabupaten Karangasem. Metode penelitian kualitatif yang digunakan umumnya bertujuan untuk mengembangkan konsep atau pengembangan suatu fenomena, dalam hal ini yaitu Peran Competitve Advantage dalam Pengembangan Agrowisata Abian Salak di Kabupaten Karangasem. Jenis data yang diperlukan dalam penelitian ini adalah data primer dan data skunder. Data Primer menurut Margono ( 1996 ) adalah data yang secara langsung diperoleh dari sumber informasi pertama, seperti data hasil wawancara, data hasil observasi dan sebagainya. Menurut Moleong (2007), data primer adalah data yang diperoleh dari pengamatan berperan serta dan data hasil wawancara langsung dengan informan. Sedangkan data Skunder adalah data yang diperoleh dari sumber-sumber yang sudah ada. Data ini biasanya data dari perpustakaan atau dari karya ilmiah terdahulu. Penelitian ini adalah penelitian kualitatif terfokus pada observational Case Study.

\section{PEMBAHASAN}

\section{A.Gambaran Umum Tempat Penelitian}

Desa Sibetan yang berlokasi di Kecamatan Bebandem, Kabupaten Karangasem, memiliki potensi yang sangat besar untuk dikembangkan menjadi sentra agrowisata berbasis salak. Letak Desa Sibetan sangat strategis, memiliki tanah yang subur dengan lingkungan sejuk, aksesibilitasnya mudah dicapai dan dekat dengan pusat-pusat ekonomi dan pemerintahan. Jarak Desa Sibetan ke pusat kecamatan hanya $2 \mathrm{~km}$, ke ibu kota kabupaten $7 \mathrm{~km}$, ke ibu kota provinsi $67 \mathrm{~km}$, dan ke Bandar udara $78 \mathrm{~km}$ (Lampiran 2). Desa tersebut terletak pada ketinggian 500 - 700 meter di atas permukaan laut, suhu udara berkisar dari 23 29 0C, dan curah hujan rata-rata $2.000-2.500 \mathrm{~mm} /$ tahun (Profil Desa Sibetan, 2014). Penduduk Desa Sibetan berdasarkan profil desa tahun 2014 adalah sebanyak 
8.725 jiwa (laki-laki 4.342 jiwa dan perempuan 4.383 jiwa) dengan jumlah kepala keluarga sebanyak 2.186 KK. Ironisnya walaupun wilayahnya subur dengan ikon sebagai sentra pengahsil salak di Bali, ternyata sebanyak $344 \mathrm{KK}$ $(15,74 \%)$ penduduknya tergolong rumah tangga miskin (pra sejahtera). Masih banyaknya penduduk pra sejahtera memerlukan partisipasi semua pihak untuk ikut berkontribusi dalam mengentaskannya.

Luas wilayah Desa Sibetan mencapai 1.125 ha, sebagian besar merupakan lahan kering/tegalan (912,62 ha) yang ditanami tanaman salak, sedangkan sisanya dipergunakan sebagai lahan pekarangan, persawahan dan lahan lainnya. Dominasi penggunaan lahan untuk salak $(81,12 \%)$ meyebabkan lebih dari $80 \%$ mata pencaharian penduduk menggantungkan hidup dari komoditi salak sehingga sejak dulu Desa Sibetan terkenal sebagai sentra produksi salak di Bali. Dengan hamparan kebun menghijau pada bentang alam yang unik, desa ini memiliki panorama alam yang indah dengan view gunung (Gunung Agung) di Utara, view lembah di Timur dan view pantai di Selatan. Udaranya bersih, sejuk, dan menyegarkan sehingga sangat potensial dikembangkan sebagai tempat tracking atau tempat peristirahatan bagi wisatawan mancanegara maupun domestik. Hal tersebut semakin diperkuat oleh lengkapnya berbagai sarana prasarana yang ada seperti listrik, telpon, internet, dan air PDAM.

Agrowisata Abian Salak di Sibetan Karangasem Bali memiliki pesona keindahan yang sangat menarik untuk dikunjungi.. Agrowisata Abian Salak di Sibetan Karangasem Bali sangat cocok untuk mengisi kegiatan liburan , seperti liburan panjang akhir tahun, libur nasional ataupun pada saat libur hari Raya. - Keindahan Agrowisata Abian Salak di Sibetan Karangasem Bali ini sangatlah menarik untuk dikunjungi karena memiliki daya taik wisata yang berbeda dan cukup unik jika dibandingkan dengan desa wisata lainnya di Kabupaten Karangasem.

Beberapa Keunggulan bersaing ( Competitive Advantage ) dari Agrowisata Abian Salak, sebagai berikt :

1. Agrowisata Abian Salak di Sibetan Karangasem Bali merupakan tempat wisata yang memiliki pesona keindahan alami berbasis perkebunan salak yang luas dan sejuk. Penduduk lokal sangat ramah terhadap wisatawan lokal maupun wisatawan mancanegara.

2. Desa Sibetan adalah nama sebuah desa di Kecamatan Bebandem yang memiliki potensi alam pertanian khas tanaman salak. Hampir seluruh penduduk di desa ini menjadi petani salak yang tersebar merata di sisi kanan dan kiri sepanjang jalan desa dan jalan raya utama. Buah salak yang dihasilkan oleh desa ini sangat 
terkenal sebagai salak Bali yang memiliki citarasa tersendiri dan berbeda dari buah sejenis dari daerah lain di Indonesia.

3. Adanya kelompok sadar wisata Dukuh Lestari yang siap membantu para petani salak untuk mengembangkan perkebunan salak tetap lestari dan berkelanjutan. Terdapat 15 jenis varietas salak yang tumbuh di Desa Sibetan, beberapa di antaranya merupakan produk unggul, seperti salak nenas dan salak gula pasir yang rasanya sangat manis, segar serta daging buah yang tebal..

4. Masa panen raya Salak Bali yang jatuh pada Bulan Desember - Pebruari membuat produksi salak melimpah sehingga masyarakat setempat mengembangkan produk olahan buah salak menjadi beraneka ragam jenis, seperti wine, dodol, kripik, syrup, dan manisan. Obyek agrowisata ini banyak dikunjungi dan mendapat perhatian dari para peneliti dan mahasiswa.

5. Jejeran pohon salak sepanjang jalan desa yang ditata rapi menjadi daya tarik agrowisata salak Sibetan. Saat ini telah dilakukan regenerasi tanaman salak dari berbagai jenis yang dikemas dalam paket-paket kebun salak untuk memudahkan pengunjung mengenal varietasnya.

6. Fasilitas Agrowisata Abian Salak di Sibetan Karangasem Bali bisa dibilang sebuah wisata alam yang memiliki beberapa fasilitas dan pelayanan di antaranya, area parkir kendaraan, rumah makan, kamar mandi / MCK, tempat istirahat, penginapan

7. Transportasi bagi wisatawan disiapkan kendaraan khusus untuk wisatawan domestik maupun mancanegara untuk mengunjungi Agrowisata Abian Salak di Sibetan Karangasem Bali.

8. Pemandangan alam yang menghadap Gunung Agung yang menjulang tinggi dengan keberadaan puluhan meru suci bertingkat memberikan aura spiritual bagi wisatawan yang berkunjung ke Pura Besakih.

9. Infrastruktur yang lengkap menuju lokasi Agrowisata Abian Salak untuk dapat menikmati kekhasan aroma kopi biji salak ( coffee Salacca ).

10. Tata kehidupan masyarakat yang tradisional dan spiritual yang tetap dijaga oleh kaum mudanya.

Ada empat kreteria Keunggulan Kompetitif berkelanjutan sebagai berikut : 


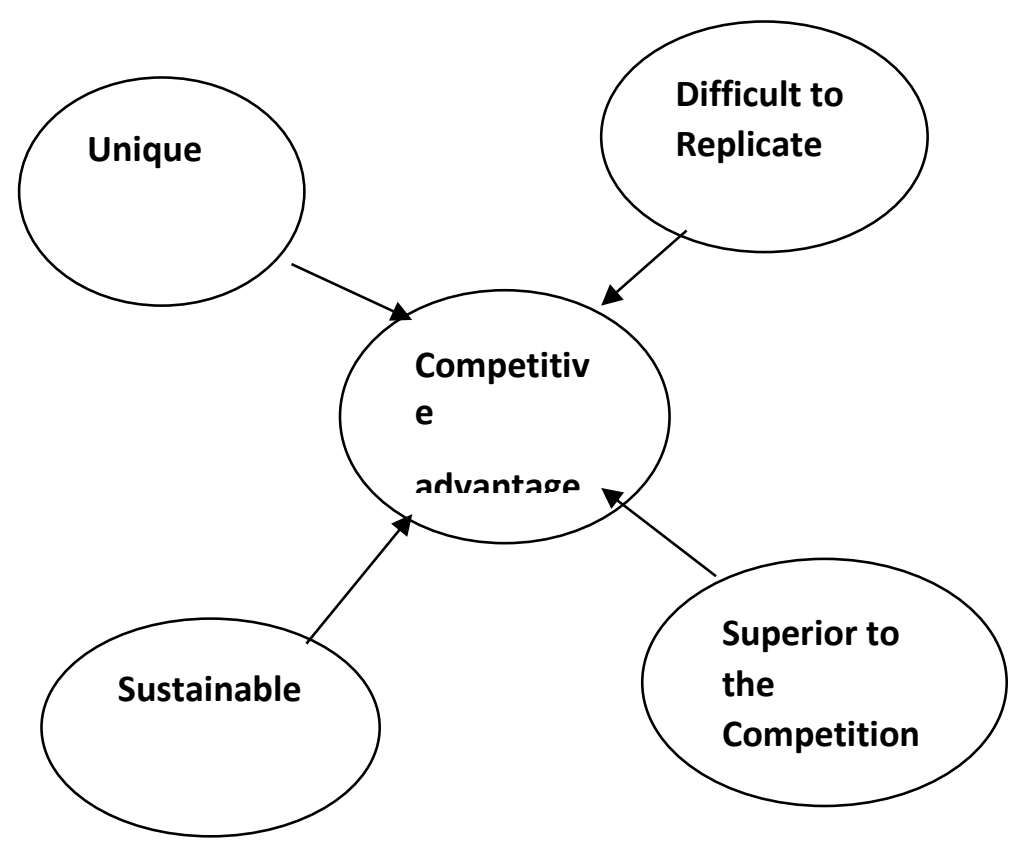

Gambar 1 Kreteria Keunggulan Kompetitif ( Competitive Advantage )

Dari Gambar diatas dapat di jelaskan keunggulan Kompetitif dari Agrowisata Abian Salak, antara lain :

1. Keunikan dari buah salak dengan berbagai varietas dan rasa yaitu manis, dan buah salak dapat diolah menjadi berbagai produk makanan berkualitas, seperti dodol salak, camilan atau kripik salak yang gurih dan minuman segar dimiliki oleh Agrowisata Abian Salak yang jarang ditemukan di wisata agro lainnya di daerah Karangasem.

2. Difficult to Replicate bahwa agrowisata Abian Salak sulit ditiru karena agrowisata ini berbasis pertanian kebun Salak dan pemandangan Gunung
Agung bagaikan lukisan indah yang sulit dicari di daerah lain

3. Superior to Competations dimiliki oleh agrowisata Abian Salak unggul diantara kompetitornya, memiliki produk salak berkualitas dengan biji salak yang bermutu diolah menjadi salacca coffe dengan pemasaran yang baik.

4. Sustainable artinya keunggulan buah salak dan produk kopi biji salak yang dijadikan produk unggulan serta alam pedesaan yang masih alami dan berlanjut dan diperkirakan akan mampu survive diatas 20 tahun.

\section{Kesimpulan}

1. Berdasarkan analisis Keunggulan Kompetitif (Competitive Advantage) 
diperoleh hasil bahwa Agrowisata Abian Salak memiliki keunggulan kompetitif dibandingkan beberapa obyek agrowisata lainnya, produk inovatif dengan menciptakan kopi khusus dari biji salak, variasi makanan camilan dari buah salak dibuat kripik, dodol salak, minuman dari buah salak dengan aroma unik.

2. Keunggulan Kompetitif secara umum Agrowisata Abian Salak menjadi ikon pemasok buah salak yang terbanyak ke kabupaten lain di Bali dan dikenal juga smemiliki keunggulan kompetitif yang berarti tingkat persaingan usaha Agrowisata cukup tinggi dan dapat diandalkan sebagai keunggulannya yang dapat membedakannya dengan wisata agro lainnya.

3. Agrowisata Abian Salak Sidemen sudah dikenal

\author{
baik oleh wisatawan \\ domestik maupun \\ mancanegara yang khusus \\ meneliti tentang kopi \\ merupakan wisata alam \\ berbasis pertanian .
}

\section{Saran}

1. Agrowisata Abian Salak untuk meningkatkan promosi dan kunjungan wisatawan, pihak pengelola agar lebih optimal memanfaatkan digital marketing untuk dapat menembus pasar yang lebih luas. Bekerjasama dengan stake holder (pemangku kepentingan ) dan melibatkan masyarakat pedesaan dalam pelatihan kewirahusaan yang berkelanjutan.

2. Agrowisata Abian Salak dapat dikembangkan dengan melihat potensi alam pegunungan yaitu Gunung Agung sebagai gunung tertinggi di Bali yang memberikan aura spiritual bagi wisatawan yang datang ke agrowisata ini. 


\section{Daftar Pustaka}

Inskeep, Edward, 1991.Tourism Planning and Integrated and Sustainable Development approach, page 66

Nicely,Annmarie, Sydnor, S., 2015, Tackling a Culture of Local Non Partisipants in a post Levery Soceity, Vol.54 .717-729

Ming Sue, et al. 2019, A Study Effect of EcotourismEnvironment Image and Word of mouth on Tourism Intention, Vol27 ( 106 ) : 599 604

Margono,1996, Metodelogi Penelitian Pendidikan.PT.Rineka Cipta; Jakarta

Moleong, Lexy J.2007, Metode Pneleitian Kualitatif. Remaja Rordakarya,Bandung

Porter, Michael, 1990. The Competitive Advantage of Nations.New York: Free Press

Porter, Michael, 1991. Towards A Dynamic Theory of Strategy, Strategic Management Journal, Vol.12, 95-117, 1991

http://disparda.baliprov.go.id/id/Statist ic 4 ( Cited on March, 2020 )

http://www.rappler.com/indonesia/118 577-bali pulau terbaik-keduadunia

Dinas Pariwisata Provinsi Bali, 2018. Bali Tourism Statisic 2018, Nangun Sat Kerthi Loka Bali
BPS Provinsi Bali, Badan Pusat Statistik Provinsi Bali, 2016, Denpasar dalam Angka Denpasar ( ID ) : BPS

Undang - Undang Kepariwisataan Indonesia, No.12 Tahun 2009 